\title{
"Que se vuelva el mundo como se estaba". Literatura y religión en el tema americano del Siglo de Oro: la polémica política
}

\author{
Ceferino Caro López
}

IES “Leonardo da Vinci”, Madrid

En este trabajo se intenta poner de manifiesto el desarrollo de la función de la polémica política en tres textos, Relox de Príncipes, Cortes de la Muerte y Numancia. La característica de estas obras consiste en que hablando de América se trataba de problemas políticos suscitados en España, a saber, los deberes morales del europeo ante el indio, vistos desde la óptica de la religión y la política. Para este fin los escritores se habían valido de la figura del buen salvaje, que estaban retocando y que a partir del Descubrimiento adquiere un significado específico, pasando de ser una figura meramente folclórica a convertirse en un referente político.

En la época inmediatamente posterior al descubrimiento de América, la dificultad extrema en la tarea de aprehensión de la realidad recién conocida consistió en el hecho de que, a la vez que se la describía y analizaba, fue necesario construir el utillaje teórico e ideológico para interpretarla. Algunos intentaron aplicar a las Indias las tradiciones, los criterios y los valores paradigmáticos que habían impregnado la antigüedad clásica y la mentalidad medieval, que parecía que el Renacimiento acababa de barrer, pero los autores más conscientes del hecho radicalmente nuevo intentaron explicarlo partiendo de los elementos de novedad que encontraban en América. ${ }^{1}$ De aquí que el habitante del Nuevo Mundo y su figura se presentaran en la escena como material para alimentar las funciones que el autor hubiera querido señalarles, de tal manera que bien pronto el indio americano adquirió valor simbólico con el doble mito del buen salvaje hecho hombre o el del bárbaro en quien cabían todos los vicios. Más tarde, desde la mitad del Quinientos y sobre todo a partir de los últimos años del siglo XVI y primeros del XVII, fue toda América la que fue asumida como connotación de una función signifi-

1 La dualidad de las sendas culturales abiertas con los autores contemporáneos al Descubrimiento se manifiesta también en los estudiosos actuales al momento de encarar el hecho histórico. Pueden tomarse como ejemplo de ello las posturas encontradas de Gil-Bermejo García, J.: "Ideas sobre el indio americano en la España del siglo XVI", La imagen del indio en la Europa moderna, Sevilla, 1990, págs. 117-125: "En este contexto cabe señalar un aspecto interesante: las sorpresas y novedades no provocaron extrañas imaginaciones de tipo medieval", pág. 118, y Alvar, M.: "Fantastic tales and Chronicles of the Indies", Amerindian images and the legacy of Columbus, Jara-Spadaccini, eds., Minneapolis, 1992, págs. 163-182: "The code of chivalry as a principle that makes possible the transmission and understanding of the New World for the West”, pág. 163. 
cativa en la producción literaria e ideológica, tanto es así que, como dice Alvar, la literatura adquirió vida y la vida se tornó literatura, porque los cuentos fantásticos, las historias clásicas y las evidencias materiales se tomaban todas al mismo nivel cognoscitivo. No se personificaba el dato geográfico, sino que el Nuevo Mundo era investido del valor de escenario en el que se desarrollaban hechos de gran significación: allí tenía lugar la elaboración patriótica de la exaltación de los españoles y de sus gestas.

El primer aspecto bajo el que se presentaba al lector el tema americano en la literatura española del Quinientos fue, como no podía dejar de ser, el de la polémica desencadenada tras los hechos del Descubrimiento y las denuncias de Las Casas. El modo en que se había realizado la conquista y la colonización de América se puede ver, desde el punto de vista de la historia de las ideas, en P. Sainz y Rodríguez mientras que López Alonso y Elorza, en El Hierro y el Oro, pasan revista a los aspectos políticos en España. Fueron precisamente las presiones de Las Casas las que obligaron a convocar en 1550 una junta de teólogos en Valladolid, en la que tuvo lugar el choque entre Sepúlveda y el dominico y, como era imposible ocultar la sinrazón de los españoles en América, "de aquí nace un fenómeno excepcional: la insólita mala conciencia de la conquista, anticipadora de la problemática que en siglos más cercanos ha de suscitar el moderno colonialismo europeo", como demuestra el que Carlos V no perdiera nunca de vista las recomendaciones a su hijo a propósito de las medidas a tomar para alcanzar la justicia en el Nuevo Mundo. ${ }^{2}$ En los orígenes de esta actitud está Las Casas, cuyo pensamiento es la raíz de la Leyenda Negra que tantos resquemores parece sigue suscitando a casi cinco siglos de su formulación primitiva, tanto es así que algunos autores incluso hoy día tildan al fraile de "empecinado orgullo", definiéndole como "andaluz desaforado" que se aferraba a las doctrinas teológicas sin buscar en ellas una justificación de la misión

2 Sáinz y Rodríguez, P.: La evolución de las ideas sobre la decadencia española, Madrid, 1925, págs. 27-28 y 36-43; y López Alonso, C. y Elorza, A.: El Hierro y el Oro, Madrid, 1989, págs. 59, 37, 93-94. Sobre Las Casas, Abellán, J.L.: "Los orígenes españoles del mito del 'Buen Salvaje', Revista de Indias, Madrid, 1976, núms. 145-146, págs. 157-189; Id.: Historia crítica del pensamiento español, Madrid, 1979; Id. Los españoles vistos por sí mismos, Madrid, 1986. Adorno, R.: "Discourse on colonialism: Bernal Díaz, Las Casas and the Twentieth-century reader", Modern Language Notes, n. ${ }^{\circ} 103,2$, Baltimore, 1988, págs. 239-258; Benítez Rojo, A.: "Bartolomé de Las Casas: entre el infierno y la ficción”, Modern Language Notes, n. ${ }^{\circ}$ 103, 2, Baltimore, 1988, págs. 259-288; Galmés, L.: Bartolomé de las Casas defensor de los derechos humanos, Madrid, 1982; Hanke, L.: Bartolomé de las Casas, The Hague, 1951; Id.: All mankind is one, De Kalb, 1974; Hernández Morelli, R.: "La praxis lascasiana a la luz del análisis gramsciano de los intelectuales y su función social, en la conmemoración del primer contacto de España con América", Literatura hispánica, Reyes Católicos, Descubrimiento, Barcelona, 1989, págs. 32-37; O’Gorman, E.: Cuatro Historiadores de Indias, México DF, 1979; Ortega, J.: "Las Casas, 
española y por lo tanto reo de antipatriotismo. ${ }^{3}$ El objeto de este trabajo es el estudio de la literatura de ficción, por lo que se pueden soslayar las referencias a los tratados de política que en el Quinientos ponían en tela de juicio la licitud y la justicia de la conquista y los debates sobre los títulos que justificaban la dominación española en América. La figura de Las Casas es probablemente excepcional por el calado histórico de su obra, por la pervivencia de sus afirmaciones y la vehemencia con que propagó y defendió sus ideas.

Hacia mediados del siglo XVI, entroncando en la tradición renacentista erasmista y fuertemente influida por los contenidos de la Brevísima Relación lascasiana, nació una obra literaria que más abajo se analizará y que es emblemática de una actitud ante América, las Cortes de la Muerte, para muchos un hito en la producción literaria de tema americanista, "y [que] repite muchos de sus argumentos" según Morínigo. ${ }^{4}$ Para la comprensión cabal de la postura de quienes se colocaban críticamente enjuiciando el Descubrimiento y el proceso de la conquista de las Indias Occidentales es necesario enfocar brevemente el tema del indio americano.

\section{El doble tema del buen salvaje y del indio depravado}

De todas las funciones que el argumento americanista tuvo en la literatura del Cinco-Seiscientos, la más radical fue la que se presentaba enjuiciando el valor político del Nuevo Mundo y el sentido de la presencia

\footnotetext{
reformador social y precursor de la 'teología de la liberación'”, Cuadernos Hispanoamericanos, n. ${ }^{466}$, Madrid, 1989, págs. 67-88; Zamora, T.: "La controversia política del destino de América en el siglo XVI", Cuadernos Hispanoamericanos, n. ${ }^{\circ}$ 373, Madrid, 1981, págs. 15-26; Dille, G.F.: "El descubrimiento y la conquista de América en la comedia del Siglo de Oro", Hispania, n. ${ }^{\circ} 71$, Univ. Southern California, Los Angeles, 1988, págs. 492-502; Cro, S.: Realidad y utopía en el descubrimiento y conquista de la América hispana (1492-1682), Madrid, 1983; Adib, V.: "Los indios en la Historia de Motolinía", Ábside, T. XIII, México, 1949, págs. 89-94; García García, A.: "La ética de la Conquista en el pensamiento español anterior a 1534", La ética en la conquista de América, Salamanca, 1984, págs. 77-104; Alcina Franch, J.: El descubrimiento científico de América, Barcelona, 1988; Esteva Fabregat, C.: La corona española y el indio americano, Valencia, 1989; Fernández Buey, F.: La gran perturbación, Barcelona, 1995; Padgen, A.: La caída del hombre natural. El indio americano y los orígenes de la etnología comparativa. Madrid, 1988; e Id.: "Rights property and ligitimation", La imagen del indio..., págs. 61-76.

3 Hernández Sánchez-Barba, M.: Historia y Literatura en Hispanoamérica (1492-1820), Madrid, 1978, pág. 62; para la leyenda negra, véase García Cárcel, R.: La leyenda negra, Madrid, 1992. Véanse también Martinengo, A.: "Los enfoques de la cuestión indiana: Las Casas reenunciador del mensaje colombino", La imagen del indio..., págs. 297-317; Mignolo, W.D.: "When speaking was not good enough. Illiterate barbarians, savages and cannibals" Amerindian images..., págs. 317-345; Milhou, A.: "El indio americano y el mito de la religión natural", La imagen del indio..., págs. 171-191; y Mora Mérida, J.L.: "la visión del indio por los eclesiásticos europeos de los siglos XVI y XVII: notas sobre la idea misional en Europa”, Ibídem, págs. 197-217.

4 Morínigo, M.A.: América en el teatro de Lope de Vega, Buenos Aires, 1946, pág. 43.
} 
española en él. La elaboración renacentista de la historiografía, en la que mucho influyera Maquiavelo, había producido la idea de que el vencedor era siempre el más fuerte y había desvinculado la posición victoriosa de la ética o de la moral religiosa, por lo que no habrá que extrañarse de que contemporánea y consecuentemente, por reacción, naciera la figura de un nuevo vencedor, "materialmente perdedor, el más débil, la víctima, vencedor moral, espiritualmente superior". 5

Desde Guevara hasta Rousseau, en la Edad Moderna, América asumió como valor principal precisamente su novedad, entendida como inocencia radical, como negación de la degeneración ética del Viejo Mundo y los habitantes del nuevo continente, absolutamente mejores que los europeos, se revestían de una carga utópica porque representaban al hombre nuevo, nuevo pero que podía degenerar a su vez y de ahí la pasión puesta al denunciar las atrocidades culturales y morales cometidas en el Nuevo por el Viejo Mundo. De este modo se realizaba un proceso de idealización abstracta, mediante el cual el nativo americano, en adelante el indio, era deshistorizado, despojado de su auténtica realidad y convertido en el buen salvaje. Transformado, no inventado, porque el personaje ya era conocido desde toda la Edad Media. El descubrimiento de América, en este caso, sólo dio la posibilidad de reforzar o reelaborar literariamente este personaje, así que el buen salvaje es una continuación del viejo tema del hombre salvaje enriquecido con los matices propios de una tradición misional - y por lo tanto interesada - que se remontaba a la Edad Media.

Baudot ha señalado cómo y cuánto está en deuda la construcción de la imagen del otro - el indio americano de Motolinía - con la cultura franciscana cuyas raíces se pueden encontrar en Giovanni da Pian del Carpine y su Historia Mongolorum. ${ }^{6}$ Este mito está estrechamente relacionado con otro igual o más famoso, el de la Edad de Oro, cuyos contenidos no eran

5 Cro, S.: Realidad y utopía en el descubrimiento y conquista de América Hispana (14921682), Madrid, 1983, págs. 221-224. Sobre el valor de la utopía en el descubrimiento, véase Fernández Herrero, B.: La utopía de la aventura americana, Barcelona, 1994.

6 Me parece muy interesante lo que puntualiza S. López Ríos ("El concepto de salvaje ...”), a propósito de la definición de los nativos americanos en el siglo XVI y la caracterización de "salvaje": "para referirse a ese desconocido ser mítico, fruto de la imaginación humana, a medio camino entre el hombre y la bestia, que vive apartado de la civilización, en bosques y selvas, y uno de cuyos rasgos más característicos es estar cubierto de pelos", pág. 148; también págs. 149-150 y 150-152. No hay que olvidar el buen criterio de García Cárcel, La leyenda ..., pág. 232, para establecer el cambio de actitud ante los indígenas del Nuevo Mundo. También Baudot, G.: "Amerindian image and utopian project. Motolinia and millenarian discourse”, Amerindian images..., págs. 375-400. En la misma línea de análisis escriben Duviols, J.P.: "Los indios protagonistas de los mitos europeos", La imagen del indio..., págs. 377-388; y también Mora Mérida, "La visión del indio...”, Ibídem, págs. 197-217. 
solamente estéticos sino fuertemente marcados por motivos y deseos utópicos o ideológicos, como ha señalado Maravall. En tiempos del emperador aún era posible la utopía de la Edad dorada, de la vida sencilla opuesta a los afanes de la corte y los tráfagos de la ciudad. Los humanistas habían encontrado campo abonado para la recepción del mito del buen salvaje en el clima cultural de la alabanza de aldea, pues veían a los indios americanos como seres que habían sabido mantenerse en un nivel ideal de "virtuosa mediocridad"; 7 Sin embargo cumple poner en guardia acerca de la diferencia entre la idea del buen salvaje mitológico y la representación de los indígenas del Nuevo Mundo tal y como se da en la literatura de los siglos XVI y XVII; entre los humanistas americanistas, como los ha llamado Maravall, quienes hablaban del primero se referían a los segundos, bajo unos ropajes distintos y por supuesto con unos fines muy diferentes de los de aquéllos que nunca siguieron la elaboración del mito del hombre primordial y ahistorizado.

Es extraordinariamente importante para comprender plenamente el alcance y las dimensiones culturales de la invención del personaje indiobuen salvaje notar que, a la luz de los estudios citados hasta ahora, se puede trazar la diferencia profunda de cómo se realizaba la aproximación cultural al problema por los hombres de la Iglesia y por los escritores. La formulación del problema de la existencia del otro, de un ser distinto en la fundamental unidad de la condición humana, ocurre con fines de evangelización, mientras que los escritores posteriores, recurriendo a la figura del indio, adoptaron una postura mucho menos problemática, aceptando los "estereotipos de uso cotidiano [...]. El indio era una persona de constitución débil y de condición social ciertamente humillada". ${ }^{8}$ Era la visión moral de los nativos por parte de los gobernantes y el hecho de que fuera la que muchos dramaturgos transmitieran sin crítica deberá hacer que lamentemos las ocasiones perdidas para construir en el teatro americanista del Siglo de Oro un carácter humano de tal y tanto alcance. Y si no se hizo no fue por falta de capacidad - Hamlet, Segismundo, Don Quijote son contemporáneos - sino por falta de interés. La figura del indio en la literatura tiene un valor instrumental, igual que lo tenía para los escritores reli-

7 Maravall, J.A.: Utopía y contrautopía en el "Quijote”, Santiago de Compostela, 1976, págs. 172 y 192, y todo el capítulo VI; también Id.: "Un Humanisme tourné vers le futur", L'Humanisme dans les lettres espagnoles, Tours, 1976, págs. 337-348; Martí, A.: "La utopía en Don Quijote”, Anales Cervantinos, Madrid, 1991, págs. 45-72, especialmente págs. 47-53; sobre la comedia de indios, véase Mazur, O.: The wild man in the Spanish Renaissance and Golden Age theatre. A comparative study. Ann Arbor, 1980, pág. 329.

8 Esteva Fabregat, La corona..., pág. 106. 
giosos. Éstos desarrollaron una aproximación interrogativa y creadora, mientras que aquélla lo redujo a un mero detalle.

Pero también en este aspecto la elaboración estética del contenido americanista fue lenta, pues hasta la primera "comedia de indios", El Nuevo Mundo Descubierto por Colón (1598-1603) de Lope de Vega, sí aparecen en la escena buenos salvajes, pero no tienen ningún punto en común con los nativos americanos, siendo más bien comparsas de las muy ideológicas obras de pensamiento publicadas en España a raíz de la difusión de la Utopía de Moro. Parecería como si los escritores no hubieran visto de inmediato las posibilidades puramente literarias de este recurso y se limitaran sencillamente a usarlo para razonamientos claramente políticos y, de hecho, estéticamente esas aplicaciones fueron escasas o no aprovechadas, pues no se consiguió crear un tipo literario parecido al del "gracioso", "valentón", "celoso", "cornudo", "galán" o incluso al del "indiano", entre los muchos que hay en las Letras españolas del Cinco y, sobre todo, del Seiscientos. Ni siquiera en la Araucana de Lope, pieza que tiene por argumento la representación de la pasión de Cristo ambientada en tierras del Nuevo Mundo, se puede decir que los indios americanos sean buenos salvajes, porque si hay figuras positivas, como la de Jesús o el Bautista, encarnadas por Caupolicán y Colocolo, también el diablo es un indio, Rengo, en este caso un salvaje malo. Incluso si se mira en la Araucana original, de Ercilla, que sin embargo exalta a los nativos chilenos, se verá que tampoco se puede hablar de elaboración del mito del buen salvaje porque los indios son presentados como seres históricos, reales, con sus ideales positivos - lucha por su honor y por su libertad- pero también negativos, con las pasiones propias de todos los hombres. ${ }^{9} \mathrm{Ni}$ por encima, ni por debajo. Lo mismo ocurría en los otros textos mencionados, textos que, aun ani-

9 Ercilla, A. de: La Araucana, (1569), ed. Morínigo-Lerner, Madrid, 1979; Oña, P. de: Arauco domado, (1596), ed. J.T. Medina, Santiago de Chile, 1917; Santiesteban y Osorio, D.: Quarta y quinta parte de la Araucana, Salamanca, 1597; Gerli, E.M.: "Elyseum and the Cannibals", Renaissance and Golden Age. Essays in honor of D.W. McPheeters, Potomac, 1986; y Laferl, C.F.: "América en el teatro español del Siglo de Oro", El Teatro descubre América, Madrid, 1992, págs. 169-269, especialmente págs. 219-222. Sobre la presencia del mito del buen salvaje, véase también Cro, S.: "Montaigne y Pedro Mártir: las raíces del buen salvaje", Revista de Indias, n. ${ }^{\circ}$ 190, Madrid, 1990, págs. 665-685; Deyermond, A.: "El hombre salvaje en la novela sentimental", Filología, T. X, Buenos Aires, 1964, págs. 97-111; Durand, J.: "El chapetón Ercilla y la honra araucana”, Ibídem, págs. 113-134; König, H.J.: "La visión alemana del indio americano en los siglos XVI y XVII", La imagen del indio..., págs. 127-156; Levin, H.: The myth of the Golden Age in the Renaissance, Don Mills, Ontario, 1969; y Ortega Medina, J.A.: "El Indio absuelto y las Indias condenadas en las Cortes de la Muerte", Historia Mexicana, T. IV, 1954-1955. Desde el punto de vista de las implicaciones religiosas, véase Delumeau, J.: El miedo en Occidente, Madrid, 1989, págs. y 141 sigs. También Gerli, “Elyseum...”, págs. 85-86 y 91. 
mados por tensiones ideológicas, eran ante todo piezas literarias y como tales querían presentarse al público. Pero los escritores críticos, los polemistas, hacían política, no estética y sus razones necesitaban de un material humano más contundente: éste era el buen salvaje. Era un modelo a priori y por lo tanto aparece en la producción americanista con una función muy concreta, esto es, de polémica política y de crítica de la conquista.

Sin embargo en otros escritores el indio era ya la imagen absolutamente positiva, que sólo precisaba de la intervención de la religión para que realizara la perfección que guardaba en potencia. La diferencia era enorme en relación con los escritores políticos como Las Casas y Vitoria; para éstos el indio era manso y sobre todo indefenso; las críticas lascasianas se dirigían a la crueldad de los conquistadores para con un pueblo que no les había hecho nada, que era inocente, reafirmando la injusticia de una violencia desencadenada contra quienes no tenían culpa alguna. Precisamente porque eran inocentes se desmontaba la pretendida justificación de la guerra justa: no había habido ninguna injuria previa para justificar la brutalidad europea. Para Las Casas y Vitoria los indios eran hombres, no bestias. Para los creadores del mito del buen salvaje los indios no eran sólo hombres, sino el prototipo del hombre bueno, más que hombres, la meta de la utopía. En este sentido se puede decir que el mito del buen salvaje no es el soporte de la crítica a la dominación europea sobre el Nuevo Mundo, sino un instrumento colateral para poder llevar adelante algunos aspectos de esa crítica. El mito del buen salvaje se halla al final, como producto de un planteamiento y no al principio, como base de una visión del mundo.

Indirectamente había sido el mismo Colón quien había proporcionado las primeras armas a los críticos de su descubrimiento, con la imagen idílica que creó gracias a la descripción en rosa del Nuevo Mundo y de sus habitantes. Más tarde la historia de la conquista no seguiría ningún talante humanitario y la práctica administrativa y política de la encomienda bien pronto causaría alarma y execración entre algunos colonizadores, indignados con el trato que se daba a los nativos. Las voces de protesta pudieron oírse en la Península y en Ultramar, desde el famoso sermón de Montesinos en 1511, en el que exigía para los indios el mismo respeto y la misma dignidad de todo hombre necesitado de evangelización e instrucción. Hasta esa fecha no parece que a las mentes de los castellanos se hubiera asomado la figura del buen salvaje. ${ }^{10}$

10 Hanke, All mankind ... pág. 4; y Kadir, D.: Colombus and the end of the Earth, Berkeley, 1992, especialmente capítulo VI, págs. 137 y sigs. 
Es interesante notar que en muchas de las principales obras de la literatura del Siglo de Oro los nativos americanos hacían de héroes positivos o de personajes centrales, con rasgos de dignidad y honor comparables con los de sus enemigos blancos, en la primera mitad del período estudiado: en Guevara, en las Cortes de la Muerte, en Ercilla... mientras que, sobre todo en el siglo XVII, el indio en otros textos literarios sólo conseguía un papel "de todo punto irrelevante" como dice Laferl a propósito de Tirso de Molina. ${ }^{11}$ Esto ocurre porque los indios no eran los protagonistas de la acción, sino el objeto sobre el que actuaban los conquistadores, y hacían a lo sumo de comparsas en obras destinadas a hablar de y a los españoles, cuyos compatriotas aparecían en los primeros planos de la trama. El indio era un personaje secundario y un personaje que se revestía de los ropajes positivos o negativos según los períodos y los objetivos del autor que lo trataba. En el caso del indígena visto favorablemente, los escritores de entre los siglos XVI y XVIII estaban incluso demasiado contentos de haber dado con un actor de carne y hueso para un personaje que era ya medieval y que ahora tomaba un carácter positivo, mientras que la tradición anterior lo había cargado de los vicios y defectos más repugnantes. ${ }^{12}$ De Juan de Maldonado a Bernardin de Saint Pierre cambia la imagen del indio porque ha cambiado la función que se le atribuía en el metatexto, de tal manera que la literatura interesada transformaba al indio de carne y hueso en carne de mito. Naturalmente ningún escritor habría llevado a cabo la mitificación del etíope, del chino o del turco; eran tipos humanos demasiado conocidos, demasiado cercanos, demasiado gastados por la historia, demasiado probados por la experiencia. En cambio el Nuevo Mundo era el nuevo tiempo, la posibilidad de emprender una nueva historia libre del lastre del pasado y de sus condicionantes, con nuevos sujetos que parecían interpretables según la voluntad del autor. ${ }^{13}$

11 Laferl, "América..." págs. 239 y 133-136. Para la posición de Tirso ante el problema político de la dominación europea en América, Caro López, C.: "Tirso de Molina, indios y encomenderos", Revista de Indias, n. ${ }^{\circ}$ 210, Madrid, 1997, págs. 345-367.

12 Deyermond, Hombre salvaje...; la Oratiuncula de Maldonado, citada en Rico, F.: "Humanisme et dignité de l'homme", L'Humanisme..., págs. 31-50; Caminero, J.: "El motivo del oro en la literatura española del siglo XVI", Literatura Hispánica..., págs. 57-72; para Francia, véase Chinard, G.: L'Amérique et le rêve exotique dans la littérature française du XVIIIe siècle, Paris, 1934; Id.: L'exotisme américain dans la littérature française, Génève, 1978. Una curiosa interpretación del mito del buen salvaje es la hallada por Maldonado, F.: "Baltasar Gracián y las Indias", Homenaje a Gracián, Zaragoza, 1958, págs. 131-135, referida a las Indias Orientales pero indicativa del proceso global de mitificación.

13 Es por tanto una vez más evidente que el nativo americano fue un invento de sus descubridores. Antei, G.: "L'Invenzione del regno del Cile", La imagen del indio..., págs. 237-288; Bénassy-Berling, M.C.: "Pedro Cieza de León frente a los indios: incomprensión y conocimiento, certezas y dudas", 
De hecho casi todas las obras de la primera mitad del siglo XVI que tratan directa o indirectamente del Nuevo Mundo son de carácter moralizador o polémico. El Villano del Danubio y las Cortes de la Muerte son el espejo de la fuerza de la Brevísima Relación de Las Casas y sus repercusiones, que se reflejan tanto en la literatura como en la política. En todos estos casos la imagen de América ofrecida por los autores demuestra a las claras no una voluntad de ilustrar neutralmente sino de orientar la opinión del lector, mediante una elaboración de la realidad original enmarcada en los esquemas mentales habituales de la época. Más tarde, a partir de la época de la Contrarreforma, el tema americano quedará englobado en la teoría de la educación por medio de la imagen ${ }^{14} \mathrm{y}$ las nuevas realidades serán presentadas bajo la doble vertiente del fortalecimiento de los estereotipos y mitos culturales o también como justificación o crítica de la acción política. Por ejemplo, si la desnudez adánica del indio se podía aceptar como muestra de su radical esencia paradisíaca, todo el sistema de la encomienda tal y como se había implantado en América había de aparecer monstruosamente injustificable; si, por el contrario, se tomaban en consideración las prácticas bestiales de canibalismo entre los indios, entonces todas las críticas de la actitud de los blancos para con los nativos perdían su razón de ser. Se trataba, por lo tanto, de elegir según los intereses de cada polemista la imagen que mejor se hiciera a sus fines.

En todo este proceso el Viejo Mundo estaba aplicando al Nuevo un sistema de referencias que no era el suyo propio y cuya única finalidad consistía en reducirlo a datos comprensibles y aceptables en el contexto de la cultura europea o en este caso concreto de la española. España impuso su

Ibídem, págs. 289-295; García Pabón, L.: "The indian as image and a symbolic structure", Amerindian images..., págs. 530-564; Jiménez, A.: "Imagen y cultura. Consideraciones de la antropología ante la visión del indio americano", La imagen del indio..., págs. 77-84; Keen, B.: "The European vision of the indian in the sixteenth and seventeenth centuries. A sociological approach", Ibídem, págs. 101-116; König: "La visión alemana...", Ibídem; Moffitt-Sebastián: O Brave new people. Albuquerque, 1996; Pietschmann, H.: "Visión del indio e historia latinoamericana", La imagen del indio..., págs. 1-11; Winius-Hoogeveen: "A legend in black and white: the Amerindian indian and the propaganda in the Eighty Years War”, Ibídem, págs. 43-59. Sobre el racismo literario ante el indio, véase Barnett, L.K.: The ignoble savage. American literary racism, 1790-1890, Newport-London, 1995; aunque trata de un período y un ámbito geográfico distinto, desvela los mecanismos de creación de una realidad cultural dirigida.

14 López Baralt, L.: "La iconografía política de América”, Nueva Revista de Filología Hispánica, T. XXXII, México DF, 1983, págs. 448-461; Jorgensen, P.A.: "Shakespeare's Brave New World", First Images of America, Berkeley, 1976, págs. 83-89; Baader, H.: "La conquista de América en la literatura española", Romanische Forschungen, núms. 2-3, Frankfurt am Main, 1978, págs. 159-175; Espacio geográfico-espacio imaginario. El descubrimiento del Nuevo Mundo en las culturas italiana y española, Cáceres, 1993; García Sáiz, M.C.: "La imagen del indio en el arte español del Siglo de Oro", La imagen del indio..., págs. 417-432; y López Baralt: "La iconografía política..." 
realidad interpretativa dando origen a dos visiones de su actuación en las Indias - la rosa y la negra - pero las dos habían sido generadas siguiendo los mismos métodos constitutivos.

Lo que puede dar razón de la interpretación del tema americano en España es por lo tanto su contexto político y cultural; durante toda la segunda mitad del siglo XVI la dinámica estuvo marcada por la desaparición del erasmismo del campo de la vida intelectual y el paso de España de una posición política hegemónica en Europa a otra de repliegue. Es una realidad que ha visto perfectamente Keen al hace notar que "from the accession of Philip II to the throne (1556), the pro-Indian policies identified with Las Casas and partially supported by Charles V were effectively abbandoned". ${ }^{15}$

\section{La crítica de la conquista en la literatura}

En las Letras españolas del Siglo de Oro la crítica política de la conquista se manifiesta en la primera mitad del Quinientos, sobre todo al coincidir con el período de máxima expansión del erasmismo y viene a chocar casi frontalmente con la ideología de los conquistadores, al menos con esa que expresa Bernal Díaz del Castillo en su crónica. ${ }^{16} \mathrm{El}$ comportamiento de los conquistadores, según este autor, se habría regido por una ética que les era común, de consagración al servicio de Dios y a la grandeza de $\mathrm{Su}$ Majestad, teniendo siempre por norte la observancia de las reglas de la caballería. Estas afirmaciones tendrían mucha importancia en la segunda elaboración ideológica de la conquista, la de los escritores nacionalistas, pues les ofrecía una serie de declaraciones, casi de "testimonios", de la auténtica actitud de los españoles en América. Pero era una visión interesada, ideológicamente orientada tanto como la de los escritores erasmistas. Para ellos el punto central de su planteamiento era el irenismo humanista, en cuyo nombre se condenaba cualquier tipo de violencia y con mayor razón la que se ejercía sobre una población inocente:

"En lo que yo he andado, que es bien la tercera parte del mundo, no he visto gente más virtuosa y pienso que tampoco la hay en las Indias..."

15 Keen: "The European vision...", pág. 107.

16 Grunberg, B.: "El universo de los conquistadores en la Historia Verdadera de Bernal Díaz del Castillo", Revista de Indias, T. XXXIX, Madrid, 1979, págs. 111, 119-120. 
según el Viaje de Turquía, ${ }^{17}$ con lo que se decía que los habitantes del Nuevo Mundo eran un término de parangón para la virtud.

Pero el texto que representa el punto culminante de esta actitud fue las Cortes de la Muerte de Hurtado y Carvajal y de la que ya se ha subrayado el erasmismo. De hecho la línea de continuidad es evidente incluso en la presencia literal de afirmaciones de autores evidentemente erasmistas como Valdés, sacadas del Diálogo de Mercurio y Carón, ${ }^{18}$ donde se dice

"Fuime a un reino nuevamente por los christianos conquistado, y diéronme dellos mil quexas los nuevamente convertidos, diziendo que ellos havían aprendido a hurtar, a robar, a pleitear y a trampear..."

mientras que la Muerte en sus Cortes $^{19}$ reiteraba que los cristianos habían enseñado a los indios "a hurtar, a robar, a pleitear y a trampear".

La condena de la actividad de los españoles en el Nuevo Mundo no podía ser más clara y la ironía valdesiana la hacía aún más cruda con el uso de ese adverbio, "nuevamente": lo que era nuevo, el mundo y quienes desde hacía poco — nuevamente - habían sido convertidos, se habían cargado, gracias al ejemplo de los evangelizadores, de los vicios más típicos y antiguos del Viejo Mundo.

La condena política de estos autores comprometidos era muy distinta de la que realizaban los escritores europeistas; para los segundos la conquista fue intrínsecamente mala porque importó a España los vicios de los indios y corrompió las sanas y viejas costumbres europeas, mientras que para los americanistas el sentido de la infamia se invertía, acusando a los "civilizadores" de estropear un mundo virgen con sus maldades. En el fondo se trataba de participar de las polémicas entre erasmistas y "maquiavélicos", donde la posición de los primeros era la de Las Casas, exigiendo la aplicación del bien y la justicia en sentido religioso a los asuntos del mundo, mientras que en el campo contrario, por ejemplo, Ginés de Sepúlveda compartía con Aristóteles la opinión de que los hombres nacen naturalmente libres o esclavos por natura. ${ }^{20}$

17 Viaje de Turquía, (1557), ed. F. García Salinero, Madrid, 1980, pág. 457.

18 Valdés, J. de: Diálogo de Mercurio y Carón, (1530), Madrid, 1971, pág. 19.

19 Rodríguez Puértolas, J.: "Las Cortes de la Muerte, obra erasmista", Homenaje al Profesor W. Fichter, Madrid, 1961, pág. 655; y Carvajal-Hurtado: Cortes de la Muerte, (Toledo, 1557), ed. J. Sancha, BAE 35, Madrid, 1855, pág. 31. Véase también White Navarro, M.G.: The imaginary space of America in the Golden Age drama, Ann Arbor, 1989.

20 Cro: Realidad..., pág. 128. 


\section{Las Cortes de la Muerte}

Publicada en Toledo en 1557, esta pieza formalmente medieval —una elaboración de la tradicional Danza de la Muerte - presenta en su escena XIX las quejas de los indios. La obra es de evidente corte erasmista, con su contraposición entre piedad exterior puramente aparente y los hechos concretos, pues los indios decían que eran más felices cuando aún eran paganos que tras la evangelización de los españoles, porque éstos habían sido la causa de sus males. Ante la Muerte los americanos venían

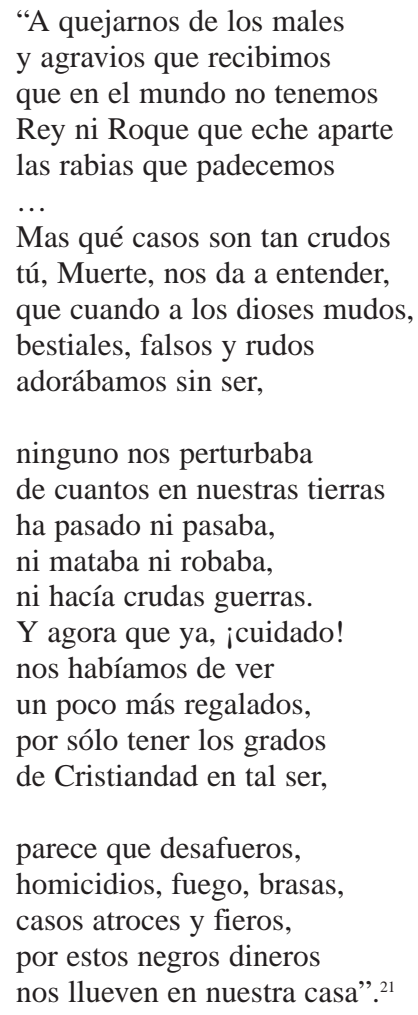

Es la crítica erasmista a los lobos con pieles de corderos. En el coloquio Del comer pescado de Erasmo ${ }^{22}$ hay una discusión sobre la difusión

21 Carvajal-Hurtado: Cortes..., pág. 31; White Navarro: Imaginary space....

22 Erasmo: I Colloqui, ed. C. Vasoli, Milano, 1967, pág. 243. 
del cristianismo en el mundo de principios del siglo XVI y el balance no es muy halagüeño: una zona de Europa hacia occidente y el norte, otra más limitada al sur y a oriente hasta Polonia. En el resto de la Tierra sólo hay paganos. Cuando el interlocutor pregunta al carnicero del diálogo si no se ha enterado de los nuevos territorios "marcados con la cruz de Cristo" —evidente referencia a América-, aquél responde que sí, pero que también sabe que en aquellos parajes eran más llamativas las rapiñas de los conquistadores que la llegada de la verdadera fe. Las palabras y el pensamiento del maestro, como se puede ver, daban la línea de argumento a sus seguidores en España. La denuncia de los horrores de la dominación española se fundaba en las fechorías de los blancos y la religión no valía para justificar nada, porque a los indígenas se los seguía maltratando incluso tras haber abrazado la verdadera fe. El diagnóstico de la situación era la codicia de los castellanos, que había sido tanta como para llegar a cortar los dedos para robar unos anillos, o las orejas para llevarse unos pendientes, que había impulsado a cometer tanta violencia, tantos homicidios ...

Se daba la vuelta a la teología de la evangelización:

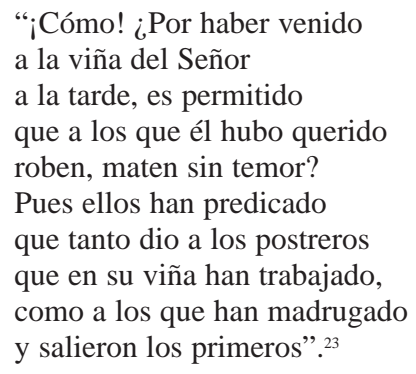

Parecería que la pregunta fuera a enjuiciar el sentido de la Providencia y sus designios en el campo de la predestinación, rozando peligrosamente la desesperanza y/o la herejía, pero la clave de la respuesta a las interrogaciones de los indios está a este lado de la ortodoxia, en el valor salvífico de la fe, en el poder irénico de la religión. Las décimas siguientes insisten en la oposición entre mensaje religioso y prácticas de los evangelizadores. Pero las críticas de los autores de las Cortes de la Muerte se templaban en su contenido ideológico con la solución que la Muerte ofrecía a los indios: la paciencia cristiana para soportar los males del presente y, desde luego,

23 Carvajal-Hurtado: Cortes..., pág. 32. 
aceptar siempre los dictados de la religión. A pesar de la virulencia de la crítica ante la realidad de la conquista, el efecto ideológico final era claramente apaciguador, en el caso de que alguien se hubiera enfervorizado demasiado por las arengas pro derechos de los nativos. En este sentido, las Cortes de la Muerte recoge el eco de la actitud lascasiana pero para darle una respuesta menos radical que sus planteamientos. La intervención en la escena de San Agustín, Santo Domingo y San Francisco, predicando obediencia y resignación, determinaba la significación final del texto. Condenando la actividad de los españoles en América se planteaba el problema del justo modo de gobernar las Indias y del justo trato a sus nativos, pero sin dejar el menor resquicio a la posibilidad de poner en tela de juicio el status quo de fondo, esto es, el dominio mismo de los europeos. Y a bien mirar, el mensaje de los santos que aparecen en la obra no iba dirigido sólo a los nativos americanos sino al público peninsular que presenciaba la representación, para acallar más las protestas en casa que las ultramarinas. En este sentido, Las Cortes de la Muerte tienen más valor en su parte de crítica que en la constructiva de bosquejar alternativas concretas.

La denuncia de las injusticias cometidas por los españoles no era el único punto polémico de la obra de Carvajal y Hurtado. El razonamiento lógico del discurso filoamericanista llevaba a los autores a demoler las pretendidas razones de la guerra justa, rechazando cualquier ius conquistae:

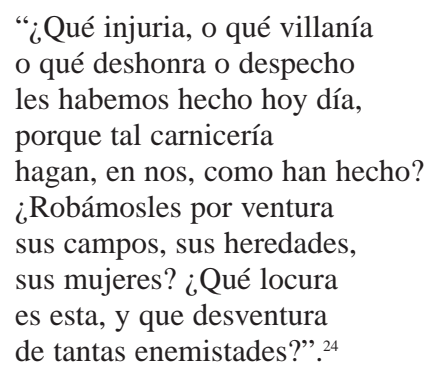

Es la evidente argumentación indigenista según la cual no se podía esgrimir un estado de guerra ante un pueblo que no había hecho nada a sus agresores. Pero la contestación que da la Muerte es demasiado acomodaticia, recomendando paciencia y fe, puesto que si el Señor ya había liberado a los indios

24 Ibídem. 
"De otros demonios mayores

... creedme que os librará

destos lobos robadores". ${ }^{25}$

Desde luego que en este texto la Muerte, que debiera ser el juez de todos los acontecimientos, se presenta también como abogado, y ello para quitar fuerza subversiva a la crítica de la situación indiana.

\section{El Relox de Príncipes}

Indudablemente, los autores más importantes en sus críticas a la conquista de América fueron, en el universo literario, junto con Hurtado y Carvajal, Guevara y Cervantes en la Numancia. La relación entre estos dos últimos autores es patente en el desarrollo del dramático choque entre razones de los vencedores y derechos de los vencidos. Guevara, ${ }^{26}$ en el episodio del Villano del Danubio, fundamentaba su posición polémica en el elemento moralizador de crítica de la codicia de riquezas de sus tiempos, apoyada en la convicción de la Edad de Oro y del estado de bondad primigenia de los llamados "salvajes". El alcance político de los discursos guevarianos era muy calculado, pues por los años en que escribía el Relox de Príncipes - 1528 - Carlos V estaba preparando su coronación en Italia. Con el episodio de los Garamantes, junto con el del Villano, Guevara construía dos parlamentos hechos ante el poder conquistador por representantes de sendos pueblos que habían sido vencidos y cautivados por los vencedores y criticaban duramente la fuerza que se les había hecho a la vez que reclamaban su libertad y dignidad.

El Relox de Príncipes contiene dos episodios directa y explícitamente relacionados con el asunto americano; aunque en ninguno de ellos se menciona en ocasión alguna el Nuevo Mundo, es evidente por su conteni-

25 Ibídem, pág. 33.

26 Redondo, A.: Antonio de Guevara (1480-1575) et l'Espagne de son temps: de la carrière officielle aux oeuvres politico-morales, Génève, 1976, págs. 662-663 y págs. 658 y sigs. Sobre Guevara, Bataillon, M.: Erasmo y España, Madrid, 1979, págs. 621 y 696; Correa Calderón, E.: “Guevara y su

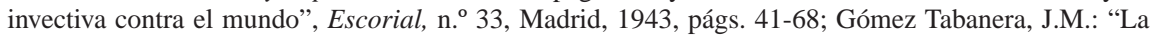
plática del Villano del Danubio de Fray Antonio de Guevara", Revista Internacional de Sociología, Madrid, 1966, págs. 297-316; Jones, J.R.: Antonio de Guevara, Boston, 1975; Rallo, A.: Antonio de Guevara en su contexto renacentista, Madrid, 1979; Del Río, A.: Moralistas castellanos, Barcelona, 1962; y Caro López, C.: "Las minas del Perú, concubinas de los ambiciosos", Anuario de Estudios Americanos, T. LV, 2, Sevilla, 1998, págs. 441-458. 
do que los capítulos dedicados a los Garamantes y al Villano del Danubio no son relleno anecdótico con sabor a mundo clásico sino referencias políticamente orientadas hacia la situación contemporánea.

Los Garamantes con toda evidencia encarnan el tema del hombre de naturaleza, que vive en un estado paradisíaco. Sin embargo esa forma de vivir no produce un ser rudimentario o primitivo, un salvaje en suma por muy bueno que sea. Los Garamantes viven revestidos de un altísimo concepto de su dignidad personal y lo expresan en los capítulos XII y XIV, al decir que para ellos es mejor "tenerse en mucho" y "tener poco" que lo contrario. ${ }^{27}$

Significativamente el discurso de los Garamantes, como el del Villano del Danubio, lo pronuncia un representante de esos pueblos ante el poder que los oprimía -Alejandro y Roma, respectivamente. El paralelismo con las Cortes de la Muerte salta a la vista: en ésta los indios se dirigen al sumo poder, la Muerte, pero en la España de 1557 y su órbita el máximo poder era el emperador, mientras que el Relox de Príncipes fue escrito inmediatamente antes de la coronación de Carlos V. Leyendo así estos textos, desaparece la ambigüedad de la postura de la Muerte en la obra de Carvajal y Hurtado, pues ser juez y parte - es decir, tener capacidad para enjuiciar y enderezar las injusticias denunciadas - sí era una prerrogativa del césar. Y en Guevara los dos episodios mencionados se presentaban precisamente como ejemplos de actos injustos de gobierno.

Los Garamantes guevarianos despreciaban cualquier tipo de riqueza y su propuesta era un programa fundado en la filosofía cristiana del mensaje primordial del Evangelio teñido con mucho de estoicismo. Era un programa ético, a diferencia del de Carvajal y Hurtado, más fideístico del que sostenía el Villano del Danubio, donde primaba la justicia política. Guevara ha graduado su intervención crítica en relación con la conquista introduciendo primero en su libro la exaltación de la vida sencilla de los indígenas — en sus aspectos materiales - para poder pedir más tarde para ella el mismo respeto y los mismos derechos políticos que los que gozaban los "civilizados" europeos.

El sentimiento irénico por el que se rechazaba cualquier justificación a la guerra de conquista y la propuesta de un camino de perfección interno dan la exacta base erasmista del razonamiento. En el fondo, el discurso de los Garamantes es la puesta al desnudo de la oposición entre lo que se predica y lo que se hace:

27 Guevara, A. de: Relox de príncipes, (1529), ed. E. Blanco, Madrid, 1994, pág. 264. 
“... nosotros holgamos ser bárbaros en la lengua y ser griegos en las obras, y no como vosotros, que teneys la lengua de los griegos y teneys las obras de los bárbaros". ${ }^{28}$

Es de creer que ese "vosotros", más que a los de Alejandro, en el libro ha de entenderse arrojado a la cara de los castellanos colonizadores del Nuevo Mundo, en lo que es otra crítica a los lobos vestidos de corderos.

La intencionalidad política de los episodios del Relox de Príncipes sale a la luz del día en el caso del Villano del Danubio. Directamente el emperador empieza a narrarlo con ocasión de unos graves desórdenes acontecidos porque no había consejeros capaces de hablar claro al príncipe - papel al que en la vida real aspiraba Guevara.

El viejo campesino danubiano afeaba la codicia de los romanos por conquistar tierras de otros pueblos,

"Que ni la mar no pudo valer en sus abismos, ni la tierra no pudo assegurar en sus campos". ${ }^{29}$

Nadie estaba a salvo de la ola de expansionismo impulsada por la codicia. Parecía que el mundo no tuviera más razones que el interés y por eso algunos autores sensibles a esta acusación tuvieron que desmontar la carga explosiva que esas ideas representaban contra el movimiento de conquista de los castellanos. Elocuentemente es Lope, en su Arauco Domado de 1615 - repárese en lo tardío de la fecha—, quien se deshace de la acusación, arrancando sin embargo de un discurso de Tucapel, que es de evidente filiación villanesca:

\footnotetext{
"Si el soberano Apó juntos quisiera chilenos y cristianos españoles, no con tan largo mar nos dividiera, un sol dios diera luz y no dos soles, acá y allá de un alba amaneciera; mas quando aquí se ven sus arreboles, allá es de noche: luego quiere el cielo que se sustenten en distinto suelo". ${ }^{30}$
}

Lo que había hecho Lope, para eliminar la objeción, era volver el razonamiento en clave religiosa, mientras que antes había sido político y de derecho. De esa manera interpretaba bien la mentalidad y la ideología

28 Ibídem, pág. 271.

29 Ibídem, pág. 701.

30 Vega, L. de: El Arauco domado, (1625), ed. de A. Souto Albarce, México, 1988, pág. 130. 
barrocas. En el Renacimiento, mientras tanto, abundando en los contenidos del mensaje del sabio Garamante, ahora la acusación de tiranía y rapiña a los romanos se mezclaba con motivos típicamente contemporáneos como la fama, la gloria y la virtud, porque

"Las riquezas que se allegan por codicia y se guardan con avaricia quitan al poseedor la fama y no les aprovechan para sustentar la vida". ${ }^{31}$

Hay que notar el énfasis puesto en subrayar que los defectos principales del conquistador - codicia y avaricia — son exactamente lo contrario de las virtudes - frugalidad y generosidad — del perfecto caballero cristiano. Todo el capítulo III está dedicado, en la obra de Guevara, a condenar las ansias de riqueza de los conquistadores. En cambio decía el viejo danubiano,

"Los que estáys acá nos robáys la fama, diziendo que pues somos una gente sin ley, sin razón y sin rey, que como somos bárbaros incógnitos nos pueden tomar por esclavos". ${ }^{32}$

El capítulo sucesivo con la crítica de la guerra de conquista formulaba las preguntas que servirían más tarde para hilvanar el discurso de las Cortes de la Muerte. Guevara refutaba todos los supuestos que podían justificar el ius conquistae con una afirmación indiscutible: romanos e ilirios no eran vecinos, por lo que era imposible que entre esas dos naciones surgiera conflicto alguno. A fortiori el argumento se aplicaba a la conquista de América y después volvía a repetir sus razonamientos teológicos. Dado que los romanos/castellanos no eran en ningún caso mejores que los vencidos ilirios/indios, para éstos su derrota se debía solamente a que sus dioses estaban enojados con ellos y los habían castigado. Pero los conquistadores no podían conformarse construyendo nuevos templos, porque la religión verdadera consiste en seguir la virtud, no en las formas externas, y con su actitud hipócrita podían esperarse el mismo daño que ahora estaban infligiendo a los conquistados..$^{33}$ Aquí, con una base de pensamiento erasmista, Guevara pasaba del campo de la crítica político-moral al de la profecía apocalíptica. El fundamento seguía siendo el mismo y coherente:

“Cómo es possible que vosotros [los conquistadores] deys orden de vivir a los estrangeros, que quebrantáis las leyes de vuestros antepasados?". ${ }^{34}$

31 Guevara: Relox ..., pág. 702.

32 Ibídem, págs. 706-707.

33 Ibídem, pág. 705. 
En estas líneas se manifiesta la postura moralizadora, cuando construye su visión del hundimiento de los valores éticos que han de regir la sociedad a causa del mal ejemplo de los poderosos. La conclusión parece ser desalentadora:

"Andémonos todos á robar, á matar, á conquistar y á saltear, pues vemos el mundo está ya tan corrupto".

Ante esa visión pesimista la última parte del capítulo es una recreación del mito de la Edad de Oro, cuando no había ni enemigos, ni ejércitos, ni codicias, ni poder coercitivo. El tema del Estado da pie a Guevara para volver al asunto político y tratar de los gobernantes ineptos. Estos son quienes tienen mayores responsabilidades en los males presentes, porque favorecen a los opresores y perjudican a los más débiles y "olvidan la governación de los pueblos por darse a plazeres y vicios". ${ }^{35}$

Esas desviaciones del recto uso del poder, apunta el Villano, se deben a la corrupción en la metrópolis, tema que realmente interesaba a Guevara. Hablaba por boca de su personaje, mirando a la Corte:

“... No ha sino quinze días que entré en Roma, y he visto hazerse y proveerse tales y tantas cosas en este senado, que si la menor dellas se hiziesse allá en el Danubio, más pobladas estarían las horcas de ladrones, que no están las parras de uvas". ${ }^{36}$

La figura del Villano del Danubio debe de haber tenido, en la cultura del Cinco y Seiscientos, un gran efecto moral y el recuerdo de sus palabras tiene que haber sido embarazoso para los mantenedores de la superioridad española en América, tanto es así que a distancia de un siglo Hurtado de Mendoza en 1630 lo presentaba bajo una luz grotesca

$$
\begin{aligned}
& \text { "ya no en lo retórico, en lo fiero } \\
& \text { fue segundo villano del Danuvio, } \\
& \text { celoso universal como diluvio". }{ }^{37}
\end{aligned}
$$

De esas palabras se concluye que su intención era de hacerlo ridículo y absurdamente atento - "celoso universal" - a la dignidad y la independencia personales. Se refleja muy bien un cierto clima cultural y moral de

\footnotetext{
34 Ibídem, pág. 706. Del mismo lugar es la cita siguiente.

35 Ibídem, pág. 709.

36 Ibídem, pág. 712.

37 Hurtado de Mendoza, A.: Cada loco con su tema, Madrid, 1728, pág. 462.
} 
laxismo propio de una época jesuítica; dando al personaje una connotación cómica se intentaba quitarle su autoridad moral.

\section{La Numancia}

Un tema esencialmente semejante al de Guevara es el que desarrolla Cervantes en la Numancia, al representar el choque entre las razones del militar encargado de una conquista y la voluntad de un pueblo libre y que quería seguir siéndolo. En la obra cervantina, al igual que en la de Guevara, se hablaba de "that throbbing and excruciating problem for sixteenth century Spain, the legitimacy of the conquest of alien people by the force of arms". ${ }^{38}$

Los romanos de Cervantes hacían el papel de los expansionistas castellanos, pero con una diferencia que jugaba en favor de los primeros: en tiempos del conflicto entre Roma y Numancia el resultado no estaba empañado por consideraciones de interés religioso, mientras que Cervantes se daba perfectamente cuenta de que, en sus tiempos, los "nacionalistas" podían jugar la baza de los beneficios que la conquista había traído a la religión, y a los pueblos conquistados, gracias a la evangelización que recibían. Zimic, en un estudio muy eficaz, ha llegado a la conclusión de que "la actitud de Cervantes ante conquistadores y conquistados no es de ningún modo ambivalente, como la de Ercilla y Zúñiga en su Araucana, sino categóricamente exaltadora de los numantinos y condenatoria del imperio romano". ${ }^{39}$ Es posible encontrar en el razonamiento cervantino la conciencia de que no se podía ahondar en esa crítica política porque ahora sí que se había dado con la Iglesia.

Escrita en 1585 según sus editores, la Numancia plantea problemas de moral política acuciantes también en la actualidad, al presentar las razones del militar que desea vencer pero evitando todas las bajas posibles entre los suyos durante la guerra. Es magnífica también, en todo el texto, la oposición entre lógica militar y espíritu de resistencia de la población civil, pues para ésta la guerra es mucho más radical —y la sufre más directamente en sus carnes- que entre los soldados: aspecto actualísimo donde los haya, considerando los contemporáneos desastres bélicos. Con relación a las

38 King, W.F.: “Cervantes' Numancia and imperial Spain”, Modern Language Notes, n. ${ }^{\text {94, }}$ Baltimore, 1979, pág. 207.

39 Zimic, S.: "Cervantes frente a Lope y la comedia nueva", Anales Cervantinos, XV, Madrid, 1979-1980, págs. 116-117. 
Cortes de la Muerte o a los episodios guevarianos del Relox de Príncipes, este rasgo dramático es el que organiza y articula más profundamente el mensaje del texto cervantino: los militares romanos podían tener razón, o al menos una razón, para actuar como estaban haciendo ante los numantinos. En la riqueza de puntos de vista es donde se percibe la distancia entre el pensamiento de Cervantes y de otros autores, más ensimismados en sus convicciones: Cervantes intentaba pensar y hacer pensar y al moverse en la línea de la puesta en tela de juicio de los derechos de conquista, remitía al problema no resuelto de la presencia de los castellanos en el Nuevo Mundo. La paciencia de sus numantinos, como la de los araucanos por aquellas fechas tan en boga, no se habría rebelado contra sus dominadores

"Si el insufrible mando y desafueros de un cónsul y otro no la fatigara". ${ }^{40}$

Esa era la razón de los chilenos en La Araucana de Ercilla, y también en Dávila, por ejemplo, aunque este segundo autor sea posterior. En este sentido la Numancia podía resultar peligrosa para el pensamiento "patriótico", pues daba por justificación a las operaciones bélicas de los españoles los mismos motivos que podían esgrimir contra ellos los indios americanos.

Sin embargo la interpretación del texto cervantino se complica enormemente al intentar dilucidar si la intención del autor fue la de exaltar a sus compatriotas o criticar la acción violenta de un pueblo contra otro. Tomando en consideración exclusivamente el desarrollo dramático-histórico de la obra, no cabe duda de que Cervantes, aun reconociendo la valía personal del general Escipión, está de la parte de los numantinos que preferían perder la vida antes que la libertad. Se trataría en tal modo de la valoración objetiva pero no imparcial —en 1585- de un acontecimiento ocurrido en el 133 a.C., pero cuyas consecuencias se aplicaban al momento en que fue escrito: si hay que ensalzar sobre todo el deseo de vivir libres, no hay justificación para los castellanos en el Nuevo Mundo y los nativos tienen absolutamente razón. Desde este punto de vista el texto sería un caso cerrado, un mero ejercicio de retórica literaria, mas para negar esta tranquilidad de juicio e introducir un motivo más agudo de reflexión Cervantes presenta, a partir de I, versos 255 sigs. a las figuras de España y del Duero

40 Cervantes, Numancia, I, versos 243-244, en Teatro completo, ed. Sevilla Arroyo y Rey Hazas, Barcelona, 1987. 
en su texto. Ahora los esquemas de valoración se difuminan. ¿Qué significado tiene vaticinar para España un futuro de dominadora en el mundo, si los dominadores, en el momento en que el Duero realizaba su profecía, aparecen bajo una luz negativa? España iba a arrebatar su libertad a otros pueblos al igual que los romanos se la habían quitado a ella y por eso se lamentaba, y de esa acción iba a sacar gloria y grandeza, pero resultaba que la gloria y la grandeza de los numantinos consistían precisamente en haber defendido su libertad contra quienes querían privarles de ella. Es indudable que la profecía del Duero ${ }^{41}$ es una exaltación "nacionalista" de los destinos imperiales españoles. Cervantes armonizó entonces el aspecto de crítica de la conquista y del expansionismo castellanos integrando esos dos temas en un conjunto de significados y afirmaciones que los desmontaba y privaba de legitimidad y se halla diseminado por todo el texto.

Ante todo, el reconocimiento del peso del hado, un tema que los críticos no han puesto demasiado de manifiesto y que merecería mayor atención. A lo largo de la Numancia los augurios van dejando en claro que el destino de la ciudad está sellado. La profecía del Duero sanciona para España una posición política internacional que le corresponderá en un futuro -interpretamos, aunque Cervantes no lo dice-, que le corresponde por su valor y no por puro fatalismo. Así, no hay que buscar ni una causa política o moral que dé razón de la caída de Numancia a pesar del valor con que se defendió, ni un mérito especial para explicar el poderío español. La una estaba escrita, el otro se lo han ganado a pulso los españoles. Sencillamente todo es tan inexplicable como la vida misma, opinión muy cervantina.

Pero esta supremacía — se supone que se está refiriendo a la que España demostraba en el mundo y también por tanto en América-, debe ser animada por la virtud y la generosidad. Ahora Cervantes vuelve a acercarse a Guevara y a Carvajal y Hurtado, de los que se había alejado con sus planteamientos realistas. Y aquí de nuevo los indios hablan en la Numancia por interpuesta persona: los numantinos ofrecen paces a Escipión pues "tu virtud y valor es quien nos ceba", ${ }^{42}$ es decir, para dominar bien es preciso hacerlo demostrando unos rasgos de grandeza de carácter que no siempre todos los gobernantes habían tenido.

41 Ibídem, versos 441 sigs.

42 Ibídem, verso 261. 